\title{
Different hemoglobin thresholds for transfusion in patients with severe sepsis and septic shock
}

\author{
T Kamio $^{1 *}$, M Sanui ${ }^{1}$, M Hayakawa ${ }^{2}$, D Kudo ${ }^{3}$, K Yamakawa $^{4}$, Y lizuka ${ }^{1}$, S Saito ${ }^{5}$, K Takimoto $^{6}$, S Uchino ${ }^{5}$, T Mayumi ${ }^{7}$, \\ Y Sasabuchi', Japan-SEPTIC DIC Study Group
}

From ESICM LIVES 2015

Berlin, Germany. 3-7 October 2015

\section{Introduction}

Hemoglobin $(\mathrm{Hb})$ level transfusion thresholds in patients with sepsis who develop anemia have long been a matter of debate. In a randomized controlled trial comparing thresholds of $\mathrm{Hb} \leq 7 \mathrm{~g} / \mathrm{dL}$ vs. $\leq 9 \mathrm{~g} / \mathrm{dL}$ in patients with severe sepsis and septic shock, comparable outcomes including mortality were obtained [1], while in an observational study of those patients, higher $\mathrm{Hb}$ levels were associated with lower mortality [2]. During the resuscitation phase of septic shock, a substantial number of clinicians may have used a higher threshold of hemoglobin at $10 \mathrm{~g} / \mathrm{dL}$, as recommended in the Surviving Sepsis Campaign Guideline 2008 [3].

\section{Objectives}

In this retrospective study of patients with severe sepsis and septic shock, we investigated whether a higher transfusion threshold of $\mathrm{Hb} \leq 11 \mathrm{~g} / \mathrm{dL}$ or higher, compared with $\mathrm{Hb} \leq 9 \mathrm{~g} / \mathrm{dL}$, was associated with improved outcomes including ICU and in-hospital mortality.

\section{Methods}

This is a retrospective study from the database of the J-SEPTIC DIC study conducted in 41 ICUs, which was developed to evaluate an association between sepsisrelated coagulopathy, anticoagulation therapies, and clinical outcomes in 3195 adult patients with severe sepsis and septic shock admitted to ICUs in Japan from January 2011 through December 2013. Patients were divided into three groups with virtual transfusion thresholds according to the lowest hemoglobin levels recorded during the first seven days of ICU stay: i) a threshold of $\mathrm{Hb} \leq 9 \mathrm{~g} / \mathrm{dL}$, ii) $\mathrm{Hb} \leq 11 \mathrm{~g} / \mathrm{dL}$, and iii) $\mathrm{Hb}>11 \mathrm{~g} / \mathrm{dL}$. Patients

${ }^{1}$ Jichi Medical University Saitama Medical Center, Department of Anesthesiology and Critical Care Medicine, Saitama, Japan Full list of author information is available at the end of the article either not transfused with the lowest $\mathrm{Hb} \leq 9 \mathrm{~g} / \mathrm{dL}$ or transfused with the lowest $\mathrm{Hb}>13 \mathrm{~g} / \mathrm{dL}$ were excluded. Patients transfused with the lowest $\mathrm{Hb}$ levels $\leq 9 \mathrm{~g} / \mathrm{dL}$ or not transfused due to $\mathrm{Hb}$ levels spontaneously maintained $>9 \mathrm{~g} / \mathrm{dL}$ and $\leq 11 \mathrm{~g} / \mathrm{dL}$ were assigned to the group with a threshold of $\mathrm{Hb} \leq 9 \mathrm{~g} / \mathrm{dL}$. Equivalent assignment criteria were applied to the remaining two groups. To determine an association between RBC transfusion thresholds and mortality, multivariate logistic regression analysis was performed.

\section{Results}

Of 3195 patients, 1423 patients (44\%) received one or more RBC units during the first seven days of ICU stay. Crude ICU mortality in the $\mathrm{Hb} \leq 9 \mathrm{~g} / \mathrm{dL}, \mathrm{Hb} \leq 11 \mathrm{~g} / \mathrm{dL}$, and $\mathrm{Hb}>11 \mathrm{~g} / \mathrm{dL}$ groups was $10.9,7.3$ and $7.5 \%$, respectively $(\mathrm{p}=0.074)$, while in-hospital mortality in each group was $26.4,18.2$ and $9.4 \%$, respectively $(\mathrm{p}<0.001)$. Using multivariate analysis, higher thresholds of $\mathrm{Hb}$ was not associated with ICU mortality (odds ratios: OR [confidence interval: CI] 1.19 [0.76-1.87] and 2.37 [0.75-7.53] for $\mathrm{Hb} \leq 11 \mathrm{~g} / \mathrm{dL}$ and $\mathrm{Hb}>11 \mathrm{~g} / \mathrm{dL}$ groups, respectively, compared with $\mathrm{Hb} \leq 9 \mathrm{~g} / \mathrm{dL}$ ) or in-hospital mortality (OR 1.11 [0.75-1.66] and 0.94 [0.35-2.56], respectively).

\section{Conclusions}

In this retrospective multicenter observational study of patients with severe sepsis and septic shock, transfusion thresholds with a $\mathrm{Hb}>9 \mathrm{~g} / \mathrm{dL}$ were not associated with reduced mortality.

\footnotetext{
Authors' details

${ }^{1}$ Jichi Medical University Saitama Medical Center, Department of Anesthesiology and Critical Care Medicine, Saitama, Japan. ${ }^{2}$ Hokkaido University Hospital, Emergency and Critical Care center, Sapporo, Japan. ${ }^{3}$ Tohoku University Graduate School of Medicine, Division of Emergency and Critical Care Medicine, Sendai, Japan. ${ }^{4}$ Beth Israel Deaconess Medical Center, Division of Molecular \& Vascular Medicine, Boston, United States.
} 
Published: 1 October 2015

\section{References}

1. PMID:25270275.

2. PMID:22975891.

3. PMID:18158437.

doi:10.1186/2197-425X-3-S1-A89

Cite this article as: Kamio et al: Different hemoglobin thresholds for transfusion in patients with severe sepsis and septic shock. Intensive Care Medicine Experimental 2015 3(Suppl 1):A89.

\section{Submit your manuscript to a SpringerOpen ${ }^{\mathcal{O}}$ journal and benefit from:}

- Convenient online submission

- Rigorous peer review

- Immediate publication on acceptance

- Open access: articles freely available online

- High visibility within the field

- Retaining the copyright to your article

Submit your next manuscript at $\gg$ springeropen.com 